\title{
О МЕТОДИ ДУБИНСКОГ ИНТЕРВЈУА
}

Ancтракт: Рад је покушај да се дубински интервју преко описа његових главних карактеристика позиционира у односу на постојеће класификације интервјуа и историју његове употребе. Стога, аргументација отпочиње описом дубинског интервјуа а наставља систематичним поређењем у односу на најраспрострањенију класификацију интервјуа на структурисани, полуструктурисани и неструктурисани. Након релационог одређивања се одлази дубље у анализу специфичности методе дубинског интервјуа и то кроз његове аналитичке предности, теоријске утемељености и генералног повезивања са етичким дилемама којих истраживачи морају бити свесни.

Кључне речи: дубински интервју, друштвени контекст, личне интерпретације и знања, феноменологија, конструкционизам, етичка питања

\section{Генерално о истраживачком интервјуу}

Сагледавање људске историје се може кретати линијама прича које људи саопштавају једни другима. ${ }^{3}$ Главни медијум за то је одувек био разговор, путем кога се размењују знање, мишљења, доживљаји, искуства, исказују специфични ставови, воде дискусије итд. Интервју се ослања на ту традицију, и уз давање дефинисаног контекста управо користи методу разговора као извор знања. Другим речима, интервју је вербална и невербална размена између интервјуера и једне или више особа, где први настоји да добије веровања, размишљања, ставове или информације од интервјуисаних (Maccoby \& Maccoby, 1954).

Очигледну сличност између свакодневних разговора људи и истраживачким циљем одређеном интеракцијом између интервјуера и интервјуисаног не

\footnotetext{
${ }^{1}$ nemanja.krstic@filfak.ni.ac.rs

${ }^{2}$ Рад је настао у оквиру Интерног пројекта Евалуација и јачање капацитета Основних академских студија социјалне политике и социјалног рада (наставак пројекта), који се реализује на Департману за социјалну политику и социјални рад на Филозофском факултету у Нишу 2019/2020; број одлуке од 30. октобра 2019. године 360/1-16-8-01

3 Људске приче ни у ком случају не могу сачињавати једини извор података у истраживању прошлости, као ни садашњости. Поред нужности да се у циљу доласка до објективног знања проверава њихова истинитост поређењем више прича о истом догађају, истраживач мора да се служи и другим изворима, на пример, коришћењем институционалних извора, чиме се прибавља екстерна валидност.
} 
треба преувеличати до те мере да се не виде разлике. На првом месту треба рећи да „иако је разговор у ширем смислу за људе универзалан“ (Brinkmann, 2013: 5), тек је у периоду између касног 19. у области новинарства, и раног 20. века у области друштвених наука ова пракса сазнавања путем разговора, одређена термином интервјуисање (Kvale \& Brinkmann, 2008). Разговор две или више особа је основа интервјуа, али као део научног корпуса техника за стицање знања она има свој ужи историјски и културни контекст и њега треба јасно диференцирати од онога што се најкраће одређује као примордијални контекст комуникације (Briggs, 2007).

Бринкман добро примећује да је статус разговора у животу људи на једној страни предност, а на другој страни огроман терет за интервју. Узимајући у обзир конверзацијску реалност људских интеракција, интервју се показује као најобјективнији метод истраживања квалитативних карактеристика људских искустава, идеја и односа ${ }^{4}$. На другој страни, сама чињеница да је разговор главни инструмент испитивања, а да се он у друштвеним праксама појављује као константа, наилази се на тешкоћу узроковану засићеношћу људи разговором (Brinkmann, 2012; 2013). Поред тога, иако је наизлед лако изводити интервју јер се користите техникама које спонтано учимо током целог живота и стога није ни потребно посебно се припремати за постављање питања и праћење разговора, искуства истраживача показују управо супротно. Интервјуисање великог броја људи различитих социјалних миљеа може бити изузетно тежак, напоран и фрустријајући посао. Иако се ради о разговорима са људима, сваки од појединаца се може сматрати изазовом за себе. Интервју ситуација се може описати као сусрет са особом коју не познајете, а циљ разговора је откривање личних схватања о одређеном проблему као и специфичности таквих ставова који припадају одређеној групи људи. То практично значи да и поред скупа рутинизованих техника, разговор морате да прилагодите баш том појединцу како бисте дошли до дубљих увиђања а самим тим и релевантних података подложних накнадном теоријском уопштавању.

Разматрајући конвенционални истраживачки интервју, Губриум и Холстин (Gubrium \& Holstein, 2002) тврде да га одликују три упитне премисе. Прва

\footnotetext{
${ }^{4}$ Једна од честих критика упућена квалитативном интервјуу је да му је субјективност инхерентна. У одбрани интервјуа као научне методе, Квале истиче да интервју може да испуни неколико схватања термина објективности. Прво, интервју може бити непристрасна метода истраживања која пружа поуздано, проверљиво, неутрално, чињеничко, личним сконостима и предрасудама недисторзирано и потврдиво знање, уколико је метода пажљиво дизајнираног и спроведеног истраживања. Друго, интервју као метода може пружати податке који су интерсубјективно проверљиви и поновљиви. Објективност је овде схваћена као дијалошка интерсубјективност, што практично значи да је интерсубјективна провељивост постигнута рационалним дискурсом и реципрочном критиком између посматрача који идентификују и интерпетирају феномен. Ова врста објективности је карактеристична за квалитативна истраживања, и разликује се од објективности као аритметичке интерсубјективности, или механички мерене поузданости кодера корелацијом између независних посматрача. Треће, интервју може бити објективан у смислу одражавања природе објекта који се истражује. Овде се мора подвући да је адекватност према објекту одређена теоријским схватањем истраживаног објекта, а када се објект интервјуа дефинише као део интерперсонално схваћеног и конструисаног социјалног света, онда је квалитатвини интервју објективнији метод од метода било које природне науке која је развијена за домен нељудских објеката (Kvale, 1994: 5-8).
} 
је да интервју представља медијум који демократизује мишљеље. У сагласју са идејом о објективности интервјуа као методе истраживања у друштву, где је конверзација основни модел интеракције, тврди се да формат интервјуа претпоставља да људска бића деле заједничка искуства. А сваки члан друштва је у стању да их артикулише уколико се тако нешто од њега затражи, што суштински указује на демократизацију мишљења. Аутори истичу чињеницу да је у овој поставци мишљење (али и осећања) сваке особе на свету валидно, те да кумулацијом таквих мишљења можемо да се приближимо опису друштвене реалности. Проблем са оваквим схватањем је вишеструк, на првом месту је тешко бранити становиште о социјалној недиференцираности заједничких истустава, а томе се свакако придружује и чињеница да ће исти фактори значајно утицати на могућност артикулисања искуства у вербалну форму. Ништа мање упитна је и претпоставка да је мишљење сваког испитаника валидно. Питање валидности знања и информација учесника је блиско повезано са предметом истраживања, па се у случају истраживања теме која има и професионални или институционални оквир, експерти појављују као релевантнији информанти од других. Ипак, не смемо изоставити ни то да нека истраживачка питања која се тичу искуства или мишљења према неким општим питањима не уносе овакву разлику између мање или више релевантих информаната.

Са овом премисом је блиско повезана и слика коју истраживачи имају о информантима, а то је да су они прави бродови одговора. Потребно је само да интервјуер поседује адекватна знања и вештине како би активирао њихове личне архиве и дошао до жељених података. И ова премиса конвенционалног интервјуа је упитна јер неки одговори могу бити условљени било контекстом, природом интеракције, актуелношћу теме и сл., а све то треба довести у везу са одговорима како би се ишло ка продубљивању њиховог значења.

То нас доводи до треће премисе, која је једнако неодржива. Ради се о дуалности улога истраживача и информанта где је један првенствено вођа, јер поставља питања и одређује темпо, релевантност и теме о којима ће се водити разговор, док је примарна улога информанта да даје одговоре на постављена питања, водећи рачуна да буду што веродостојнији искуствима и догађајима о којима се говори (Исто: 4-6). Неактуелност ове премисе је видљива уколико се са конвенционалног, структурисаног интервјуа преоријентишемо на сагледавање неструктурисаног интервјуа. У њему улоге нису тако стриктно дефинисане, стално се мењају, а информант од пасивног субјекта постаје активан учесник у конструкцији верзије реалности (Исто: 16). Још треба додати да се ригидном поделом улога и начело демократичности суспендује у интервју ситуацији, јер иако су у хоризонтали сви информанти једнако вредни, у интервјуу се често појављује хијерархијска линија поделе између вође и пратиоца разговора. На ову тему ћемо се још једном вратити када детаљније разматрамо односе неједнакости у интервјуу.

Овим смо заправо дошли до диференцијације типова интервјуа. Да ли је интервју једноставан проток информација од информанта ка интерјвуера, или се пре може говорити о конверзацијској интеракцији између две или више осо- 
ба (Kvale, 1996). Можемо рећи да се ради о лажној дилеми, и да је можда наједноставнији одговор на то питање да се ради о различитим типовима интервјуа. Прва дефиниција је опис односа који се констутише у структурисаном, а други односа који преовладава у квалитативном интервјуу.

Сви интервјуи обухватају интеракцију између интервјуера и интерјуисаног, с тим што се уређивање те интеракције може значајно разликовати. Најгенералнија подела по начину уређивања интеракције је на структурисани и квалитативни интервју (Jin, 2012)5. За разлику од Јина, други аутори не говоре о тако јасној граници, већ о континууму који се простире од структурисаног, анкетног интервјуа са одређеним, стандардизованим и у већини случајева затвореним питањима, све до супротног краја где стоје неструктурисани, отворени, антрополошки интервјуи које карактеришу разговори налик пријатељским (Seidman, 2006: 15). Додатно омекшана дистинкција уводи сумњу у могућност да интервју буде у потпуности структурисан, као и у потпуности неструктурисан. Континуум се овде састоји од на једној страни релативно структурисаног до релативно неструктурисаног формата интервјуа. Чињеница да се интервју најчешће започиње неформалнијим разговором и да се тако и завршава (Parker, 2005), показује да постоје делови интеракције у којима се предвиђена структура интервјуа не поштује. По истој логици не постоји ни комплетно неструктурисан интервју, јер истраживач барем има на уму тему о којој жели да разговора што је већ рудиментаран оквир за разговор. А као што Бринкман добро примећује, не постоји питање које не води ка нечему (Brinkmann, 2013: 19), што значи да свако постављено питање смањује опсег могућности да разговор оде у неком другом смеру, а најчешће фокусира разговор ка одређеним темама.

Подела интервјуа према структури разговора није једини критеријум за њихову класификацију ${ }^{6}$. Поред њега, интервјуе можемо класификовати и према броју испитаника - на индивидуалне и групне, према стиловима интервјуисања - недирективни и директивни, или према типу медија који се користи у интервјуисању - телефонски, интернет или лицем у лице.

\section{Ситуирање дубинског интервјуа}

Питање које происходи из претходно наведених покушаја класификација интервјуа јесте, где спада дубински интервју. У циљу ситуирања дубинског интервјуа можда је најбоље почети од описа најуобичајеније класификације интервјуа на структурисан, полуструкутисан и неструктурисан. Она се такође

\footnotetext{
5 Јин преферира термин квалитативни интервју у односу на алтернативе као што су неструктурисани, интензивни и дубински јер је квалитативно интервјуисање постало значајно диверзификовано те може да укључи у било коју од варијанти у некој комбинацији.

${ }^{6}$ Разматрајући методу интервјуа, Уве Флик (Flick, 2009) даје увид у широк спектар типова интервјуа у друштвеним и хуманистичким наукама. Он наводи и детаљно описује велики број типова, међу којима су полустандардизовани интервју, фокус интервју, интервју центриран на проблем, етнографски интервју, интервју са експертима и епизодни интервју.
} 
може схватити као континуум са две тачке крајности и једном тачком која би се налазила негде између њих. Описом сваког од њих долазимо до увида где је могуће ићи дубоко у истраживање, што ће само по себи значити да се ради о оквиру који можемо означити дубинским. Читалац се овде с правом може запитати, зашто као тема рада није узет неки од типова из уобичајене типологије. Одговор на то је да критеријум класификације према структури разговора, као што смо већ описали, није логички потпуно јасан, и да термин дубински прецизније означава карактер метода квалитативног истраживања. Стога ће демаркација простора који у методолгоији заузима интервју, почети преко типологије интервјуа према структури. Наиме, разматрајући структуру интервјуа, релативно лако се може указати на опсег техника које припадају дубинском интервјуу.

Структурисани интервју је пажљиво прописан разговор између интервјуера и интервјуисаног. У њему су сва питања унапред дефинисана (као и алтернативе), и зна се тачан редослед њиховог постављања. Структурисаним интервјуом се интервју ситуација унапред дефинише чиме се спречава било каква могућност праћења непредвиђених, али релевантних и занимљивих идеја. Интервјуер у свакој ситуацији, невезано за контекст поставља исти сет питања без варијација, а већи део тих питања су затвореног типа (Fontana \& Frey, 2000: 649-650). Протоколом за вођење интервјуа је такође строго одређена и улога интервјуера и интервјуисаног, што за последицу има истоветан приступ интервјуера свим учесницима као и исто понашање у свим ситуацијама. Такође, у овом типу интервјуа се избегавају вредносно и емотивно обојена и директна питања - будући да се могу протумачити као провокативна или непријатељска (Berg, 2001). Све скупа, структурисани интервју има доста недостатака. На првом месту је склоност интервјуисаних да на тако формулисана питања дају социјално пожељне одговоре, и чињеница да уколико истраживач жели да понуди објашњење феномена са позиције интервјуисаног, мораће да се послужи спекулацијом а не аутентичном перспективом. Други недостатак је што схематизована питања и одговори не дозвољавају испитивање дубине и комплексности искустава интервјуисаних (Marvasti, 2004: 19-20). На основу описа структуре интервјуа, и његових ограничења није тешко закључити да он не може носити епитет дубинског. Предност структурисаног интервјуа би могла бити случајевима где постоји довољно знања о датом феномену, а циљ студије, на пример, јесте његова перцепција. Још једна предност би у одређеним условима била једноставнија упоредивост евиденције, тиме и њена уопштивост под условом да је узорак биран на одговарајући начин. Обе предности су свакако ограничене истраживачким питањима и цљевима, и увек је потребно сагледавати их из те визуре.

Неструктурисани интервју је потпуни опозит струкурисаном. У њему је дозвољена отворена и флуидна интеракција између истраживача и учесника. То значи да постоје идеје о чему ће се разговарати, али је то више некакав генерални смер и оквир, а учесници могу увести теме које нису предвиђене. Најважније је дати што више простора интервјуисанима да изложе своје приче, и да њихове елементе повезују на свој начин, без посебних дирекција интервјуера. 
Дакле, овај тип интервјуа прати асоцијативни ток мисли учесника разговора, а неформална ситуација у којој се интервју обавља омогућава интервјуеру да без задршке али и строгог плана учествује у разговору. Неструктурисани интервју дефинитивно отвара могућност да интервјуисани иде дубоко у опису својих осећања, мишљења и елаборацији ставова, да уз то понуди сву комплексност свог погледа на ствари и све то представи на начин који је дубоко личан. Интервјуисани има слободу да своје схватање проблема изложи кроз причу која се састоји од делова које сматра значајним. Марвасти наводи да су две варијанте неструктурисаног формата дубински и етнографски интервју, али одмах након тога истиче то да се термини „неструктурисани“, „дубински“ и „етнографски“ у друштвеним и хуманистичким наукама неизменичо употребљавају, те да се и у теорији и у пракси ове оријентације често поклапају (Исто, 2004: 21).

Полуструктурисани интервју омогућава интервјуеру да све време усмерава учесника ка темама које су релевантне за истраживање а да опет не буде превише директиван, чиме би нарушио спонтаност и аутентичност описа учесника. Полуструктурисани интервју тражи баланс између спремљених питања, којима се држи фокус, и потпитања којима истраживач тражи додатна појашњавања делова прича која сам испитаник наметне. Истраживач је уз све то у прилици да активно учествује у продукцији знања, што се може третирати као транспарентнији модус у односу на онај који се „крије“ иза водича за интервју (Brinkmann, 2013: 21), или оног којим се инсисистира на „немешању“ у теме разговора и ток мисли.

Сумарно, о дубинском интервјуу може се говорити искључиво у другом и трећем типу интервјуа, јер први због своје структуре разговора не дозвољава детаљно и дубинско испитивање тема разговора јер у потпуности и унапред одређује ток и ниво разговора. Да би се говорило о дубинском интервјуу, неопходно је дати информанту довољно простора како би његове личне интерператције и значења дошли до пуног изражаја. То не значи да разговор не треба структурисати, напротив, истраживач аналитички разлаже одређени феномен и преводи га у низ тема и даље питања која би требало да покрију све његове аспекте ${ }^{7}$ међутим, да би ишао дубоко у лична схватања, доживљаје и тумачења мора разговор да води тако да се питањима отварају теме од интереса истраживања, а да информант описима личних искустава и тумачењем усмерава даље дубинско залажење у сваку задату тему, па чак и да сам одреди тему која се може испоставити као релевантна а да је истраживач није уврстио у свој списак. Дакле, најближе оваквом опису дубинског интервјуа је полуструктурисани тип, који је уједно и најраспрострањенији у друштвеним и хуманистичким наукама, а неретко се изједначава са самим квалитативим истраживањем (Warren, $2002)^{8}$. У већини истраживања је тешко, а није ни препоручљиво, изоставити структуру. Стога сматрамо да се дубинско истраживање може вршити управо

\footnotetext{
${ }^{7}$ Бригс овај аналитички фокус дефинише као „шири скуп пракси продукције знања који креирају истраживање од почетка до краја““ (Briggs, 2007: 566).

${ }^{8}$ Сем у потпуно експланаторним истраживањима, када је неструктурисани интервју погоднији за упознавање са основним карактеристикама феномена
} 
када је структура довољно флексибилна да дозволи учеснику да буде активан, непокоран, укључен и заинтересован за тему о којој се води разговор (Latour, 2000), а да уједно омогућава истраживачу да се сигурно креће координатама проблема са довољно слободе, да у сваком тренутку може да залази у интерпретације и значења интервјуисаног.

Ако сада структурисани тип интервјуа сагледамо у односу на дубински, онда бисмо могли рећи да постоји низ аргумената за то да други свестраније користи потенцијал разговора. Најпре, учесници се могу разликовати по много чему, па тако, на пример, по томе колико су отворени или стидљиви. Дубински интервју даје могућност истраживачу да се прилагоди затворенијим учесницима, да им приђе на прикладнији начин и тиме добије више него што би добио да је поступио по клишеу интервјуер-интервјуисани. Даље, дубински интервју претпоставља концентрисано слушање учесника и активно тумачење значења изговорених речи и гестова. Укратко, он је системски напор да се разуме оно што вам други говоре (Rubin \& Rubin, 2012) и да се на бази тога поставе додатна питања, али врло конкретна и спецификована. Ставови испитаника се дубинским интервјуом доводе у везу са целокупном причом испитаника што води ка његовом разумевању, али и разумевању феномена из његове перспективе. За разлику од тога, структурисани интервју прати истраживачево схватање феномена, а преко дефинисаних фраза, директивних питања и дефинисаних опција, оно се намеће и самом учеснику.

Структурисаним интервјуом је скоро немогуће ухватити трендове или допрети до контекстуалних услова одређених значајних догађаја учесниковог живота. Дубински интервју управо супротно, даје могућност да се истраживање фокусира на тренд тиме што се задржава на његовим условима (Jin, 2012). Значај контекста у разумевању значења неког искуства најбоље је артикулисао Сеидман. Да би дошао до смисла искуства учесника, он сматра, на трагу Долбера и Шумана, да је потребно урадити три интервјуа са сваким учесником. Први интервју успоставља контекст искуства учесника, други им дозвољава да своје искуство реконструишу кроз контекст у којем је оно настало, док се трећим учесници подстичу да рефлектују о различитим значењима сопствених искустава (Seidman, 2006: 17). Само тако је могуће допрети до смислених описа искустава, јер су она без контекста лишена стварних значења њихових власника.

Додатно, предност дубинског интервјуа је и та што у њему интервјуер може да заузме различите улоге и тиме покрене учесника да исприча причу са још једне позције, да пружи више углова за исту ствар. У добијању што бољег и веродостојнијег описа одређеног феномена, интервјуер може заузети активну улогу према интерпретацијама учесника, може да примети недоследност и укаже на њу, да кроз дискусију допре до извора контрадикције у исказу или мишљењу. Такође, интервјуер може активирати и неку конкретну социјалну улогу, на пример родитељску, како би подстакао разговор на тему родитељства и дилема које та улога носи са собом9.

\footnotetext{
9 Активан приступ који се овде помиње је само донекле базиран на активном интервјуу (Holstein \& Gubrium, 1997) јер се фокус не ставља толико на питање како интеракција обликује испитаникову причу и начин на који је она изложена, већ на разумевање животних искустава из
} 
Треба још нагласити да се у неком смислу дубински интервју може видети као синтеза, а у неком као синоним за многе друге типове - као што су на првом месту полуструктурисани, активни, квалитативни или драматуршки интервјуи. Ако одемо још даље, онда можемо рећи да свака студија може да креира своју верзију различитих техника карактеристичних за неки од поменутих интервјуа, као што може да користи комбинацију неколико типова, али да неће погрешити ако се за именовање комбинације техника или типова искористи само један од наведених термина. Ми ћемо надаље разматрати дубински интервју као генеративни појам и својеврсну комбинацију карактеристика свих наведених варијанти.

\section{Карактеристике дубинског интервјуа}

Интерес за употребом дубинског интервјуа везан је за претпоставку да ће у отвореној интервју ситуацији интервјуисани бити слободнији да искаже своје ставове и да детаљније описује своја искуства (Flick, 2009: 149; Marvasti, 2004: 29). Такав начин интервјуисања се фокусира на конверзацијске могућности отварања непредвидивих тема разговора и на стално повезивање значења која својим искуствима придају информанти и контекста у којима су се догађаји који продукују та искуства одиграли.

Питања везана за продукцију знања, значења и смештање свега у шири социјални контекст, повезано је и са ширим увиђајем да се у квалитативним истраживањима не трага за принципима истине који важе у свим друштвеним условима и који немају временски оквир, дакле по угледу на законе који владају у природном свету (Rubin \& Rubin, 2012: 40). Циљ је заправо да се разуме како се ствари дешавају у сложеном друштвеном свету, како специфичне друштвене околности у интеракцији са мотивима и ресурсима појединца продукују одређена делања, и која значења актери приписују тим делањима. На том трагу, дубинским интервјуом можете допрети до личних интерпретација аспеката социјалне реалности, можете разумети конкретна искуства и на крају можете да реконструишете догађаје у којима нисте учествовали (Исто: 1-3). Не треба изоставити ни чињеницу да се дубинским интервјуом, као делом теоријски добро утемељеног истраживања, може прикупити евиденција која служи тестирању теоријских претпоставки, као што може и да послужи као грађа за њихово дефинисање када имамо недовољно или потпуно неистражен друштвени феномен (експлоративна сврха). Другим речима, друга сврха интервјуа је изразито важна у прелиминарним фазама истраживања, када се трага за проналажењем значајних веза између појава или када се долази до формулисања потенцијално плодотворних хипотеза.

Дубински интервју је специфичан по приступу који иде даље од декларативног мишљења, јер се залажењем у лична схватања долази до аутентичних

контекста у којем су настала, као и значења насталих на њиховој основи. 
података. Тако ће интервјуер да охрабри учесника да својим речима опише свој свет и то у циљу покушаја да друштвене околности видите из његове перспекитве. Ипак, истаживач се не задржава на ономе што је директно речено, већ тежи ка откривању структура и односа значења која нису одмах очигледна. Да би се то постигло, потребно је поћи од здраворазумских перцепција и објашњења одређених културних искустава, али отићи даље ка дубљим рефлексијама о природи тих искустава, затим ка њиховим контекстуалним границама (Johnson, 2002), па чак, заузимајући дистанцу током интерпретације података, и новим реконтекстуализацијама реченог у специфичном концептуалном контексту (Kvale, 1996: 201).

Још једна врло важна карактеристика дубинског интервјуа јесте могућност сагледавања и разумевања одређене теме из више перспектива. Отвореним питањима и неспутаном дискусијом могуће је открити вишеструке ставове поводом неког питања. Ставови могу бити неодређени, ни да ни не, а могу бити и контрадикторни, али управо детаљнији разговор на задату тему - разматрањем примера, хипотетичких ситуација, временском димензијом, различитим контекстима, може „разоткрити“ узроке тих „дисонанци“ јер пружа могућност да интервјуисани објасни разлоге за своје дилеме или шансу да образложи неуједначене ставове.

Употпуњавање значења и веродостојности мишљења испитаника је такође методолошки квалитет који са собом носи дубински интервју. Комуникација није састављена само од вербалних карактера, већ се одиграва и на нивоу невербалног. Интерпретација информација добијених путем комуникације заправо није ни могућа без невербалних елемената као што су гестови, фацијалне експресије, поглед, положај тела, боја гласа али и паралингвистички знакови. Тако интегрално узети (вербални и невербални) формирају цзеловит канал комуникације (Archer \& Akert, 1980). Интервјуер у интервју ситуацији може да прати невербалне сигнале интервјуисаног бележећи их као информацију која ће допунити вербалне исказе. Ти сигнали могу бити од пресудне важности, јер могу да указују на несигурност интервјуисаног када говори о некој теми, па самим тим и на веродостојност реченог. Иако се може рећи да смо на „,клизавом терену“ када разматрамо веродостојност преко невербалних знакова, не треба пренебрегнути чињеницу да људи не говоре увек истину, а да је поузданост исказа видљива у целокупном држању појединца који говори као и да је за такву интерпретацију потребна вештина која се стиче током целог живота, па је препознавање несклада готово тренутно. Ово је само један пример, начин на који учесници говоре може носити и информацију о томе шта им дата тема значи, које емоције код њих покреће и сл.

У дубинском интервјуу није могуће елиминисати „ефекат интервјуера“ јер и поред водича и других пропратних техничких елемената, он сам је главни истраживачки инструмент. Стога да би се квалитетно и ефективно комуницирало, можемо побројати неке од стратегија комуницирања које побољшавају делотворност методе дубинског интервјуа. 
1. Не инструментализовати учеснике. То значи, не третирати учеснике као једноставне изворе информација које је потребно што боље искористити за кратко време. Брижно слушање и искрена заинтресованост за личне приче центриране око идеје да интервјуер „учи од људи“ (Spradley, 1979) може плодотворно да утиче на спремност учесника да отвореније говори о свим темама.

2. Водич за интервју (протокол или сценарио). Иако је дубински интервју најчешће комбинација припремљених тема за разговор и питања која се током разговора намећу као смислени окидачи за наставак разговора ка релевантним детаљима, потребно је добро се припремити. Водич за интервју или сценарио треба да садржи главне теме, понекад разрађене и у конкретнија питања која могу добро послужити када имате случај са учесником који даје оскудне одговоре. Списак основних тема би требало проћи са сваким испитаником јер би он требало да покрива супстантивне аспекте феномена са позиције истраживача. Уз то, тако аналитички разложена дискусија о феномену касније пружа добру основу за компаративно разматрање исказа различитих учесника. Он свакако не сме да буде препрека за отварање непредвиђених тема, нити треба да буде стриктна основа за разговор. Уколико учесник нема искуства у некој од подтема, не би требало инсистирати на то да се обавезно мора и о томе разговарати jep ће то сигурно одвести ка ефемерним информацијама. Ипак, добар водич може да пружи чврст оквир разговора који је релативно лако надограђивати и прилагођавати у зависности од ситуације и искуства учесника. Неки аутори разматрају могућност да сценарио имате испред себе током интервјуа. То не мора да буде лоша пракса, јер неки учесници могу сматрати разговор озбиљнијим уколико имате папир са питањима, док друге може навести на превише формално понашање у разговору. Чешће се препоручује да упамтите све релевантне теме, а да разговор водите без ослањања на водич (Seidman, 2006; Marvasti, 2004; Yin, 2011), а да га можете имати са собом за неочекиване околности.

3. Не говорити много (удео интервјуера у разговору). Два разлога стоје иза овог принципа. Први је тај да уколико интервјуер говори много, даје мање времена учеснику за одговоре и елаборацију мишљења. Суштински се тиме ускраћује основна сврха интервјуа. Друго, уколико интервјуер говори много, постоји опасност да предодређује одговоре испитаника, или у екстремнијем исходу, да добије просте одговоре слагања или неслагања са сопственим објашњењима. Тиме се као и у првом случају нарушава логика дубинског интервјуа који служи за улажење у дубље дилеме и значења испитаниковог погледа на дату тему. Неке од стратегија за избегање оваквих консеквенци разговора су да се питања формулишу у једну реченицу, да се учесни- 
ку да простор за одговорима, а да се онда кратким питањима покуша са стимулисањем учесника да на бази оригиналног коментара крене у шире објашњавање. Дакле, интервјуер треба да буде активан у разговору, али на начин који ће поспешивати учесника да више говори, а не обратно. Овде је свакако важно избегавање директивности у питањима. Тиме се даје могућност да учесник самостално вербализује своје одговоре и што је још важније, добије слободу да дефинише који су елементи проблема њему важни и како из појединачног схвата и уобичује у целину. Учесник треба да прати свој асоцијативни низ и да у сваком тренутку показује своју перспективу проблема.

4. Толерисање тишине. Делује као императив да се говори у разговору. Интервју је баш таква ситуација која је дефинисана очекивањем да неко говори (претежно учесник). Међутим, тактичан однос према тишини је врло важан у дубинском интервјуу. Ово је нарочито важно уколико се зађе у осетљиве теме, па испитаника препалаве емоције које није лако исказати непознатој особи. Идеја је да им се у тим ситуацијама дозволи да се консолидују у тишини и да пронађу свој начин како да наставе разговор о осетљивој теми. Примере можемо наћи и у темпу размишљања, постоје људи којима је потребно да застану, размисле ,у себи“, а онда изнесу мишљење. Од користи је да у тим тренуцима интервјуер не осети нелагодност и крене у испуњавање празнине појашњавањима постављеног питања или постављањем нових, већ да правилно процени сврху тишине.

5. Неутралност у разговору. И у овом случају се разликују мишљења аутора и то по питању схватања улоге истраживача у самом разговору. На једној страни је став да све реакције на садржај учесниковог говора морају бити такве да даље не одређују одговоре и мишљење учесника. Као што то дефинише Јин, „најмање пожељна конверзација се појављује онда када учесник покушава да вас задовољи - као супротност исказивању својих искрених схватања“ (Jin, 2011: 137). На другој страни је мишљење које одбацује могућност постојања неутралности у квалитативним истраживањима. Сваки интервју је социјални однос у којем истраживач одабиром тема и питањима уноси свој поглед на проблем (Fontana \& Frey, 2000). Зато не треба избегавати конфронтирање интервјуисаног са контрадикцијама и неконзистентношћу његових исказа. Две стратегије су у оптицају за постизање објективности у овом другом приступу. Једна је базирана на мишљењу да је активан интервју прави одраз реалних (у смислу свакодневних, уобичајених) социјалних интеракција, па се тиме заправо репродукује логика стварног живота и тиме обезбеђује објективност. Друга стратегија је да се у каснијим анализама експлицирају све пристрасности и дирекције интервјуисаног и тиме појасни могућност да су неки одговори или реакције потенцијално биле њихове последице. У крањем случају, различите стратегије служе различи- 
тим циљевима студије, а дубински интервју је само оквир у којем их је могуће искористити, било појединачно било у комбинацији.

6. Одржавање добре атмосфере разговора. Добра атмосфера је првенствено одговорност интервјуера, као иницијатора социјалног односа, али се не сме заборавити да је атмосфера резултат релације, па је један део и на страни учесника. Овде се не мисли да је добра атмосфера неприкосновени принцип, али истраживач би требало да води рачуна да својим питањима не повреди, или да својим манирима не увреди учеснике.

7. Интервју је социјални однос. Иако је једним делом индивидуално изграђен (одраз личности учесника и истраживача), и иако се може третирати као острво размене одвојено од тензија категорија реалности (Seidman, 2006: 95) ${ }^{10}$, интервју се одиграва у социјалном контексту, па стога није могуће изоловати друштвене факторе који га добрим делом одређују. Етницитет, род, класа и сл. су фактори који утичу на интеракцију и о којима сваки истраживач мора водити рачуна и током разговора, али и у анализама. ${ }^{11}$

\footnotetext{
${ }^{10}$ Првенствено се мисли на слободу коју са собом може да донесе анонимност интервјуа, да се у њему могу саопштити мишљења и ставови без бојазни да ће имати тренутне и нужне консеквенце на дати однос или тренутни статус појединца. На пример, да саопштите свом надређеном да вас његове речи узнемиравају, да вам се не допада тон којим говори, да сматрате његов говор увредљивим, или безбедност да отворено изнесете политички став према одређеном органу власти или представнику власти.
}

${ }^{11}$ Ово је врло комплексан проблем и захтева посебну обраду, али ћемо само кратко указати на неке главне налазе. Проблем једнакости је главна димензија када у интервјуу имамо учеснике који се разликују према одређеним значајним социјалним карактеристикама.

Класа - на првом месту ту су класно условљене перцепције друштвеног положаја интервјуера. Истраживачи најчешће долазе из средње класе, и што је врло важно имају високо образовање за разлику од припадника нижих слојева који најчешће чине значајан део интервјуисаних. Истраживач овде мора водити рачуна о томе да не истиче симболе социјалног статуса, али и да ни у ком случају своје претпоставке не базира на свом класном искуству.

Род - може бити препрека отвореној и неспутаној комуникацији. Искуства истраживача су показала да родни односи утичу на динамику интервјуа у смислу да мушкарци у интервјуисању жена често наступају заповеднички, да интервјуерке приликом интервјуисања мушкараца теже успостављају контроле над интервјуом када дође до померања фокуса са предмета истраживања, као и да сексистички мотиви могу бити разлог за одбијање интервјуа са женом. Чак и у случајевим где су сви учесници истог рода, родни односи могу да одреде интеракцију између интерјвуера и интервјуисаног/их, па и до те мере да се може говорити о измењеном контексту самог интервјуа (Harold, 1993; Patai, 1987). Када је реч о утицају рода и класе, узраста и сл. постоји још низ перспектива повезаних са овим карактеристикама испитаника. Постоји мишљење да су жене отвореније у дискусији, да лакше дају податке о себи, да су старији сходно свом животном искуству слободнији у дискусији, да људи различитих класних позиција различито реагују на исту комуникацијску ситуацију итд.

Године - интервјуера и интервјуисаног могу бити проблем у ситуацијама где је интервјуер доста млађи, па се старији учесник осећа нелагодно у релацији где је он тај који треба да даје одговоре, a то је нарочито изгражено ако се у неку меру осећа статус подређености. Сличну ситуацију можемо имати у интервјусању млађих категорија становништва, на пример деце, која се неће лако прилагодити формалнијем виду испитивања. Свакако, и у једном и у другом случају је неопходно прилагођавање учесницима како не би се избегао неадекватни приступ са нежељеним последицама на однос. 
8. Истраживање је процес. Вођење дубинских интервјуа није истраживачка активност која би требало да буде одређена до краја на самом почетку. Анализа није фаза која искључиво следи након завршеног посла са интервјуисањем. Дубински интервју омогућава истраживачу да рефлектује и током једног интервјуа и прилагођава приступ учесниковим интересовањима, али такође и могућност да се анализирају урађени интервјуи и на бази стеченог знања прошири списак тема, или дода одређена перспектива. Другим речима, да током теренског рада спроводи секвенцијалну анализу, која може поправити квалитет прикупљених података у интервјуима који следе.

На крају описа карактеристика дубинског интервјуа, треба размотрити и статус учесника у крајњем резултату истраживања. С обзиром да интервјуисани учествују у стварању материјала за писање анализа, и то непосредније него у другим типовима истраживања, неки аутори су размишљали о томе да ли је потребно укључити их и у тој фази истраживања. Такво становиште произилази из уверења да су учесници у стању да процене да ли је написано нешто што их чини рањивим, или је у материјалу непрецизно представљен неки њихов став.

Концептуално залеђе овакве одговорности према учесницима долази од дефиниције односа између интервјуера и интервјуисаног. Присан однос са учесником, што према мишљењу неких истраживача води ка бољем интервјуу, доводи до поништавања дистанце и може продуковати тежњу ка усаглашавању ставова и мишљења. У крајњем случају „целокупан интервју транформишете у „ми“ однос у којем питање чије је то искуство и чије је то значење постаје критично збркано [...] У таквом случају интервјуер би постао једнак учесник, и резултат би био дискурс карактеристичан за разговор, не интервју" (Seidman, 2006: 96). Стварање таквог односа у интервјуу значи да истраживач мора да буде спреман да дели његове консеквенце када на ред дође писање извештаја о материјалу.

Балансиранији однос подразумева очување дистанце у интервјуу која учеснику дозвољава да аутономно формулише одговоре, тачније, што је независније могуће, јер потпуно уклањање утицаја интервјуера није могуће. Тај однос Сеидман на трагу Шицовог схватања интерсубјективног разумевања из-

Статус групе - овде се може говорити о различитим категоријама, на пример о етничкој, сексуалној или религијској припадности учесника. У сваком случају, статус групе, да ли је она мањинска група, да ли је маргинализована или сл. захтева посебно сензибилисање питања и приступа. Конкретан проблем може настати уколико интерјвуер неопрезно истиче припадност већинској групи у интерјвуу са припадником мањинске која је још и на неки начин угрожена, рањива или дискриминисана. Не треба изоставити ни чињеницу да је могуће манипулисати статусом угрожености, те да постоји објективна оправданост за испитивање баш те групе (о томе у делу о етици).

Елите - неки аутори посебно истичу интервјуе са елитама и не говоре о њима у оквиру статуса групе или класе јер се ради о специфичним условима. Наиме, елите су тешко приступачне групе; обично се захтева највиши ниво поверљивости информација; због својих позиција тешко пристају на директна питања и ситуације где немају пуну контролу над дешавањима (Mikecz, 2012). Све ово је потребно узети у обзир када се дизајнира приступ истраживању елита. 
међу две особе (Schutz, 1967), означава као „,ја-ти однос“. Њиме се истраживач не суздражава од интензитета комуникације који подразумева и изношење садржаја о себи, живе реакције и сл., али у тој мери да се пажња не преусмери са интервјуисаног на интервјуера и тиме угрози аутентичност речи интервјуисаног. Да би постигао такав однос, интервјуер мора да буде транспарентан у дефинисању и одржавању права учесника, од тога колику ће дистанцу заузети, до тога какав статус ће учесник имати у раду са материјалом (Seidman, 2006: 99).

\section{Одређивање приступа}

Теоријске оријентације које уоквирују дубински интервју као методу истраживања чине континуум од феноменолошког приступа до контрукционистичког. То практично значи да на једном крају налази приступ који примарно инсистира на томе шma се у интервјуу говори, док се на другој страни налази приступ који се фокусира на то како се разговор одвија. Другим речима, феноменолошки приступ интервјуу подразумева покушај интервјуера да добије што детаљније и прецизније описе искустава, мишљења и ситуација од учесника. Он уз то тежи да минимизира свој утицај на ток мисли (Talmy, 2010), и избор елемената интервјуисаног, како би у крајњој линији елиминисао било какав ефекат интервјуера на исказе о субјективној перцепцији стварности. Донекле, интервјуер може имати значајну улогу у повећању валидности исказа интервјуисаног тиме што ће га подсећати да покуша да искуство смести у одређени просторни и временски оквир, али и тако што ће захтевати детаљније описе који ће чинити смислену, уверљиву причу. Свакако да се тиме валидност у потпуности не постиже, јер приче могу бити кохерентне и када су измишљене, али пажљиво слушање, захтеви за додатним описима, контекстима или релацијама у којима су се догађаји одиграли, према овом становишту може значајно да утиче на поузданост исказа.

Проширењем валидације од детаљних описа ка активном комуникацијском приступу истраживач се удаљава се од „чисте“ феноменолошке тачке и креће ка другом крају континуума. Овде се пре свега мисли на идеју да се валидност исказа у интервјуу може тестирати тако што се сучељавају тврдње у самом дијалогу. Што је више покушаја фалсификације тврдња преживела, знање је валидније и поузданије. Практично, целокупни процес истраживања је овде схваћен као покушај да се знање добијено кроз интервју потврди. А то се ради континуираним проверавањем исказа кроз додатна питања која не искључују конфронтацију, али и валидацију у фази интерпретације налаза, када се указује на недоследности и недоречености, када се проверава кредибилитет, плаузибилност и поузданост налаза (Kvale, 1994). Иако се и даље задржава пажња на опису света живота интервјуисаног, пажња се додатно усмерава ка интерпретацији значења описаног феномена, а све то се смешта у концепт интервјуа као конверзацијске и интеракцијске методе која нам пружа привилеговани приступ субјективним значењима која можемо третирати као приказ субјективно кон- 
струисаног света. То свакако није довољно да се дође до главног циља у социолошким истраживањима, а то је реконструисање друштвене основе тако конструисаног доживаљаја социјалног света. Дакле, долазак до субјективних интерпретација није сам по себи циљ, већ се оне морају повезати са друштвеним факторима као што су економски, културни, социјални капитал, и из те интеракције наставити ка објашњавању друштвене условљености перцепције, доживљаја и интерптерација социјалног света.

Даљим кретањем од описа ка интеракцији, од есенцијалних значења која интервјуисани артикулише а интервјуер интепретира (Brinkmann, 2013: 24), ка значењима која су конституисана кроз интеракцију, заправо се приближавамо другом крају континуума, тј. конструкционистичком приступу. У њему се подаци добијени путем интервјуа тумаче као одраз реалности која је конструисана у самом интервјуу. Интервјуер је овде саучесник у креирању значења која су суштински постигнута кроз дијалошки процес. Унутар конструкционистичког модела нема трајних истина до којих се може доћи пажљивом употребом питања која воде ка аутентичним исказима. Напротив, овде је истраживач потпуно свестан своје улоге у заједничкој конструкцији свега што се дешава у конверзацији, а сам интервју се схвата као ситуациона пракса (Kvale \& Brinkmann, 2008), дакле, интеракција која је такође значајно одређена околностима у којима се збива.

Ближе конструкционистичком крају континуума је концепт интервјуа који долази са теоријске позиције социјалног интеракционизма и који Берг (Berg, 2001) означава појмом драматурики интервју. У основи, сматра се да су и саме методе друштвених наука односи који могу да буду предмет анализе (Warren, 2012: 130), а интервју као тип социјалне интеракције је посебно погодан за такав приступ. Са такве позиције се заправо и долази до димензије разумевања интервјуа као драматуршке ситуације. Код овог концепта је најважније разумети разлику између статички схваћене улоге интервјуера у интервјуу, и репертоара улога које је он у прилици да игра у интервју ситуацији. Полазећи од предумишљаја учесника о интервјуеру, успоставља се скуп очекивања који окружује типичну улогу интервјуера. Међутим, овај скуп само делимично детерминише улогу интервјуера, а према Бергу, „стварна концепција улоге интервјуера долази из дефиниције ситуације која се успоставља током самог тока интервјуа“" (Berg, 2001: 85). Интервјуер се, дакле, схвата као самосвесни перформер који је заједно са интервјуисаним у константном процесу играња улоге и оцењивања свог и наступа овог другог. То им омогућава слободу да се прилагођавају улози другог, да промене сценарије, или преформулишу поруке у складу са тумачењем ситуације.

Дубље у интерпретативни оквир иде постмодернистички концепт интервјуа као рефлексивне праксе. Интервју је према овој оријентацији начин писања о свету, а значења до којих се током интервјуа долази су ситуациона. Могло би се рећи, да је у самом интервјуу употребљен материјал из стварног света, али је он у крајњем продукту реконструисан, преуређен, поновно произведен и претворен у перформативни текст који захтева даље извођење ${ }^{12}$. Међутим, тај

\footnotetext{
$\overline{12}$ У покушају да лоцира историјски тренутак рефлексивног интервјуа Дензин мапира историјско
} 
текст није лишен друштвене релевантности, он је заправо критички наратив који указује на социјалне проблеме и као такав садржи потенцијал да утиче на друштвену промену (Denzin, 2001: 43-44).

Разлика између феноменолошког и конструкционистичког приступа са свим нијансама смештаним између њих би кратко могла да се сумира као разлика у схватању интервјуа као инструмента за откривање супстантивних истина у субјективним тумачењима учесника, и интервјуа као симулакрума социјалног света у којем се значења продукују кроз интеракцију између интервјуера и интервјуисаног. Ипак, треба истаћи сличност између ова два краја која чини могућим аргумент о континууму. Ради се о томе да интервју омогућава особама да испричају приче о себи које, путем анализе, истраживачу дају прилику да продукује знање о одређеним феноменима. Заједнички циљ учествовања у интервјуу је стога дељење искуства које открива истоветност (Porter, 2000), тј. оно што Шиц назива базичном сличношћу која омогућава комуникацију између мене и тебе (Schutz, 1967). Како ће се тумачити садржаји добијени у комуникацији, као и њена форма, зависи од тога од којих теоријских поставки кренете у извођење интервјуа, али основни аспект сваког интервјуа је трансфер искуства фундираног на елементарној сличности.

\section{Етичке дилеме употребе методе дубинског интервјуа}

Дискусија о етичким проблемима које са собом носи интервју би се могла ослонити на теоријску линију са две крајности. Уколико истраживач заузме конструкционистичку позицију, онда је прича о универзалим моралним судовима, процедурама или истинама склоњена по страни у корист аргументу да је моралност социјални конструкт. Интеракције интервјуа стога треба посматрати у односу на актуелне културне праксе, а морал као форму за њихову реализацију. Насупрот оваквом схватању морала стоји феноменолошко становиште које акценат ставља на идеју доследног, објективног описа света. Таквим приступом истраживач феномен ставља у контекст моралне реалности. Сами објективни, густи описи (Levine, 1998) указују на моралне аспекте догађаја. Експлицитни морални судови нису ни потребни јер је исправност датог делања видљива у самом опису. Овом приступу је етика инхерентна, појављује се као практична мудрост ${ }^{13}$, као метода расуђивања која се не ослања на универзалне принципе, већ на етички густе описе догађаја. То практично значи да се они сагледавају

поље фаза кроз које је квалитативно истраживање прошло и где се сада налази. Он сматра да се ради о комплексном пољу у којем се пресеца седам историјских периода који функционишу у садашњости: 1) традиционални (1900-1950); 2) модернистички, или златно доба (1950-1970); 3) нејасни жанрови $(1970-1986)$; 4) криза репрезентације (1986-1990); 5) постмодерни, или експериментални (1990-1996); 6) постекспериментални (од 1996. па до данас); и 7) будућност (Denzin, 2001: 25).

13 Аутори ове феноменолошке провенијенције граде своје схватање етике квалитативног истраживача на Аристотеловом појму пхронесис - практичне мудрости која омогућава човеку да одређује циљеве и начине за њихово остваривање, али да у тај процес путем рефлексије повеже циљеве са широм идејом о општем благостању, што је сматрао најважнијом људском врлином. 
у контексту који је испуњен вредностима, а тачан опис догађаја открива и њихове вредносне и етичке карактеристике (Brinkmann \& Kvale, 2005: 175-177).

Заузимање позиције која би се налазила између ове две би свакако омогућила да се задрже предности и феноменолошког и конструкционистичког приступа. То значи да у разматрању етичких аспеката односа насталих током обављања интервјуа, истраживач мора узимати у обзир етичке принципе који важе како у струци (професионални кодекс) тако и општије норме моралног понашања, али са знањем да се ради о социјално детерминисаном схватању доброг понашања, и да оно као такво нема временску и просторну универзалност, као и да је унутар једног друштва у одређеном времену могуће говорити о релативности моралних принципа у зависности од културног оквира различитих друштвених групација. ${ }^{14}$

Основни извор опрезности са којом истраживач мора да приступи извођењу дубинског интерјвуа је чињеница да се њиме залази у приватне сфере живота људи. У зависности од предмета истраживања, ова приватност има своје нивое, па се од приватности породичног живота, може ићи ка интимнијим темама појединаца. Консеквентно, објављивањем студије, постоји реалан ризик да се угрозе лични интереси, осећања или шире гледано право на приватност. Ако чак и изузмемо део последица истраживања који би припадао правној регулативи, још увек се не може говорити о етички неограниченом пољу научне праксе. Наиме, професионална удружења прописују процедуре и принципе етички исправно вођеног истраживања. Удружења за разлику од судства немају могућност да прописују законски обавезујуће санкције, али су им доступне различите мере контролисања и санкционисања представника професије ${ }^{15}$.

Дакле, дубински интервју даје приступ субјективним искуствима, личним уверењима и интимним аспектима живота учесника. Знање продуковано

\footnotetext{
${ }^{14}$ Савремена етика истраживања је доминантно произашла из биомедицинског истраживања. Као реакција на језиве тортуре, сецирања и експериментисања које су откривене током Нирмбершког процеса, а које су изводили нацистички лекари као део медицинског истраживања, америчке судије су 1947. године формулисале Нирмбершки кодекс. Иако никада није званично усвојен као закон, Нирмбершки кодекс је имао главни утицај на законе о људским правима као и на медицинску етику. Кодекс је значајан и по томе што је увео нови поглед на кључну тачку етике истраживања, те је са фокуса на одговорност истраживача према субјекту истраживања, акценат ставио на права субјекта, тачније, на то да субјект мора самовољно да пристане да учествује у студији (Shuster, 1997).

Вођена принципима установљеним Нирмбершким кодексом, Светска здравствена организација je 1964. усвојила декларацију о етици истраживања која је названа Хелсиншка декларација. Главни принцип декларације је примарност добробити субјекта истраживања у односу на све остале интересе. Извор: https://www.wma.net/policies-post/wma-declaration-of-helsinki-ethicalprinciples-for-medical-research-involving-human-subjects/, посећен 07.10.2019.

${ }^{15}$ На пример, Америчка социолошка асоцијација је 1970. усвојила свој први Етички кодекс, који је ревидиран 1984. године када је и успостављена пракса разматрања документа на сваких пет година. Извор:

http://www.asanet.org/history-asa-code-ethics, приступљено: 05.10.2019.

Знатно касније, тачније 2001. године, Извришни одбор Међународне социолошке асоцијације је одобрио Етички кодекс. Извор: http://www.isa-sociology.org/en/about-isa/code-of-ethics/, приступљено: 05.10.2019.
} 
у овим областима живота носи етичке проблеме у барем два смисла. Прво, истраживач објављивањем конкретних података може да угрози приватност интервјуисаних и компромитује њихов статус у друштву. Друго, са метапозиције, интервју који учесници нису иницирали, нити за који имају некакав лични интерес, етички је проблематичан јер може покретнути „нове самоинтерпретације и емоционалне промене“ (Brinkmann \& Kvale, 2005: 169). Најмање што у овом контексту истраживач мора да уради је да се постара да подаци које објављује не угрожавају лични интегритет нити социјални статус појединаца који су део истраживања, али и да допусти учесницима да се искажу онаквима какви јесу, али и да им да прилику да реагују, да се противе ономе што им интервјуер ради (постављајући питања) или ономе што говори о њима (Latour, 2000).

Овим смо се заправо дотакли првог и основног етичког принципа научног истраживања, а тиме и дубинског интервјуа. То је информисана или имплицитна сагласност учесника истраживања. Практично, да би се интервју уопште обавио, након објашњења циља интервјуисања, сврхе истраживања, и начина употребе података учесник може да прихвати или одбије учествовање, било потписивањем сагласности, било тиме што улази у интервју и тиме имплицито пристаје на презентоване услове. Међутим, овим се ни близу не решавају проблеми које може проузоковати истраживање дубинским интервјуом. Иако је уобичајено да се учесницима гарантује анонимност и поверљивост, и једно и друго у овом типу истраживања могу бити упитни. С обзиром да дубински интервју подразумева сусрет и упознавање са учесником (чак и потписивање сагласности), најчешће и обављање интервјуа у кући/стану учесника, анонимност практично не постоји. Зато је кључно обезбедити висок ниво поверљивости. Истраживач овде гарантује учеснику да ће све што је речено током разговора остати стриктно поверљиво, и да се неће објављивати ништа што може да ода идентитет учесника или га на било који начин доведе у опасност. Да би се ова гаранција преточила у стварност, истраживач мора систематично да преименује сваког учесника псеудонимом или бројем случаја, да уклони сваки елемент који одаје локацију или који указује на идентитет неке друге особе и сл. Током писања анализе, истраживач мора стално да води рачуна како ће износити податке, мора стално да процењује ниво ризика од употребе конкретних информација, јер неће у свим случајевима бити једнако ризично да се објави име града или насеља. Детаљност описа личних искустава, мишљења у комбинацији са увиђајем у приватност појединца, позивају на виши степен опрезности у дискусијама, нарочито када се оне стављају у социјални и просторни контекст. Чињеница да се интервјуи најчешће снимају, додатно пооштрава етичку димензију истраживања, јер дословно постоји материјални траг о учесницима, па је опасност од злоупотребе већа. Како би се она спречила, врло је важно установити и поштовати процедуре за чување и коришћење аудио и видео записа интервјуа.

Све ово сагледано из перспективе дистрибуције моћи између интервјуера и учесника, указује да је великим делом она на страни првог. Тиме се отвара ново поље проблема које, када се у игру уведу последице односа нејед- 
наке моћи, добија етичку конотацију. Првенствено је ту питање дистрибуције моћи у интервјуу. Иако улоге интервјуера и интервјуисаног могу варирати у зависности од околности, друштвене позиције учесника, рода, старости и сл. интервју готово по правилу истраживача ставља у позицију моћи. Интервју ситуација је тако дефинисана да је истраживач тај који иницира сусрет, дефинише теме разговора, усмерава дискусију и завршава разговор што све указује на асиметричну дистрибуцију моћи. Такође, интервјуер је тај који држи целокупни процес анализе и тумачења у својим рукама, а на то се надовезује и асиметрија бенефита од дубинског интервјуа. Ово последње значи да је управо интервјуер тај који захваљујући подацима из интервјуа може да напредује у каријери или да добије признање за публиковање резултата. Насупрот њему је интервјуисани чији се добитак често своди на то да ће га неко пажљиво и озбиљно слушати (Polkinghorne, 2008) ${ }^{16}$.

Поред тога, интервју није сам себи циљ, као што је то у случају пријатељског разговора, већ је инструмент за добијање података о одређеној теми, добијање наратива, и увида у сферу личног. Стога се може говорити о инструментализацији дијалога, која у неким случајевима може попримити и облике манипулативног дијалога, где интервјуер има скривени план који није очигледан на основу питања која поставља. Етичкој упитности оваквог односа у интерјвуу доприносе и приступи неких истраживача који глуме пријатељство, који циљано прилагођавају своје ставове и осећања (Duncombe \& Jessop, 2002) како би придобили поверење а самим тим и искрене одгворе.

Овим, већински етички неоправданим стратегијама, приближава се и истраживање маргинализованих група. Зашто би овакво истраживање било етички проблематично? Аргумент је да истраживачи могу користити чињеницу да је маргиналним групама лакше приступити, као и да су њихови припадници склонији томе да учествују у разговорима или пројектима за које верују да на неки начин могу да утичу на побољшање њиховог статуса, или барем повећање видљивости њихових проблема. Иако циљеви истраживача могу бити научно оправдани, типа повећање заинтересованости служби да помогну људима са социјалним пробемима, мотиви као што су доступност група, или одсуство друштвене моћи (Kelman, 1972 - за разлику од на пример високопозиционираних политичара, власника великих корпорација, топ менаџера и сл.), или придобијање угледа на конто доброчинитељства, могу бити предмет озбиљне етичке дискусије.

Један од начина да се прибави оправдање за истраживање у којем не постоји транспарентна намера истраживача је примена утилитаристичког принципа. У њему се вага између добити коју научно сазнање доноси групи или друштву и потенцијалне штете која се може нанети појединцу или групи ако се осетљиви резултати објаве. Истраживање је етички оправдано уколико се процени да је корист већа у оносу на процењену штету (Berg, 2001: 40-44).

${ }^{16} \mathrm{У}$ неким случајевима би добитак интервјуисаног могао бити и материјалне природе, у виду новца или вредносног ваучера за учешће у интервјуу. 
Очигледно је да се оваквим оправдањем може суспендовати један од најважнијих етичких принципа у друштвеним истраживањима, а то је својевољно учествовање учесника базирано на информацијама о циљевима истраживања. Утилитаристички приступ са манама које носи ипак уноси и једну врсту флексибилности јер у неким случајевима корист од истраживања заиста може бити диспаратна у односу на негативне последице по учеснике ${ }^{17}$.

Можда једно генерално схватање квалитативних истраживања, а наричито дубинског интервјуа представља највећи изазов јединственом схватању етике истраживања. Ради се о феномену који Бринкман и Квале називају етищизам, што је суштински идеја да су квалитативна истраживања етички исправна по себи, и да су као таква без упитности супериорна у односу на квантитативне приступе (Brinkmann \& Kvale, 2005: 162). Конкретније везано за интервју, тај дискурс и његова популарност има свој социјални контекст у културној промени од индустријског ка потрошачком друштву. Промена је ишла од преласка од грубог опредмећивања средстава контроле и моћи ка мекшим, заводљвијим формама моћи реализованим кроз интимне односе, дијалог и емпатију. Етика интервјуа тиме заправо прати логику потрошачког друштва која удовољава, задовољава и саосећа, и која је у тој форми сушта супротност бирократском приступу квантитативног прикупљања података. Овакво схватање етике истраживања је самим тим трансфер идеје о добром третману потрошача - вођењу рачуна о његовом задовољству - на интервју ситуацију. Етика је на тај начин инструментализована, а алтернатива је да се у интерјвуу користе форме активног конфронтирања уз поштовање интегритета учесника и уважавање културног контекста. Дубински интервју на тај начин не напушта етичке принципе, напротив, он их уграђује у себе, али транспарентно и не на штету квалитета отвореног разговора.

\section{Закључак}

Дубински интервју се великим делом ослања на свакидашње праксе људи да разговарају и размењују искуства и мишљења. Могло би се рећи да овај тип интервјуа скоро па паразитира на рутинизованим праксама људске инте-

\footnotetext{
${ }^{17}$ Познати пример је дискусија о Хемфрисовој студији Фелащио у јавним тоалетима (Теaroom trade - Humphreys, 1970). Аутор је у циљу истраживања јавних сексуалних пракси мушкараца користио методе прерушавања, обмане и манипулације. У првој фази је преузимао watch queen улогу - посматрача који поред воајерског ужитка води рачуна о потенцијалној опасности и упозорава учеснике, и тиме добио увид у детаље игре упуштања у сексулани однос у јавним тоалетима. Ту прилику је користио да забележи регистарске таблице аутомобила учесника, а да их онда пронађе у административној бази у циљу обављања интервјуа са њима. За интервју би се прерушио како га не би препознали и лажно представио као анкетар који обавља истраживање у њиховм крају. Када је студија објављена 1970. наишла је на критику због низа неетичких сегмената. Међутим, касније ревизије последица студије су указивале на то да је она допринела промени разумевања ове сексуалне праксе, што је даље утицало и на законску регулативу и социјалне мере. Не треба занемарити ни мишљење да је овај социјални феномен било врло тешко, ако не и немогуће истраживати на другачији начин, те је у одређеној мери био методолошки исправно дизајниран приступ.
} 
ракције, да богато користи то што скоро свако поседује одређени репертоар вештина погодних за интервјуисање. Али разговор у дубинском интервјуу није једнак свакидашњим разговорима, јер га карактерише специфичан тематски и временски оквир, он се не може поистоветити ни са пријатељским, јер није циљ за себе. Дакле, ради се о теоријски вођеној, истраживачким интересом детерминисаној дискусији којом се долази до дубљих личних интерпретација феномена, као и детаљних описа искустава, али и односа између искуства и значења, тачније њиховог међуутицаја.

Дубински интервју никако не може бити једнострана комуникација, нити се може одредити као техника систематског проверавања или потврђивања претпоставки истраживача, већ је интервју заједнички напор, процес пажљивог прилагођавања питања искуствима учесника, прихватања неочекиваних смерова разговора или дигресија који прате линије учесниковог знања или интереса (Johnson \& Rowlands. 2012: 107) Речју, интервјуер мора да буде отворен да напусти свој план разговора и да прати ток како би добио квалитативно богат материјал. „Изгледа да постмодерни тренд у интервјуу и квалитативном истраживању прави цео круг, и враћа се тамо где је и почело, мада рефлексивнији а мање позитивистички" (Ian Borer \& Fontana, 2012: 57).

Потентност дубинског интервјуа је можда највидљивија онда када се трага за механизмима који покрећу веома сложене активности, када је потребно нијансирати различите, вишеструке перспективе о одређеном феномену, или када су нам потребни дубљи разлози за одређене изборе и откривање конкретних склопова елемената стратегијског делања. Дубински интервју полази од здраворазумских схватања и објашњења искустава, али ту не стаје, већ продире у рефлективније садржаје да би се на аналитичком нивоу све заокружило контекстуалним границама искуства. У циљу остваривања потенцијала, примена дубинског интервјуа не сме да се сведе на познавање строго одређеног скупа техника, већ мора да укључи знања и технике произашле из феноменолошких, феминистичких, драматуршких, конструкционистичких, интепретативних концепата и методолошких консекванци.

Комбинација техника и знања која долази из различитих теоријских присупа не значи да се конкретно истраживање не треба јасно артикулисати и сместити у флексибилан али дефинисан аналитички оквир. У зависности од теоријског становишта, користиће се сасвим одређени аспекти дубинског интервјуа, тачније актуелизоваће се они елементи који ће најбоље служити теоријски постављеним захтевима. Тек када имамо јасно дефинисане теоријске поставке, и одатле произашле циљеве и истраживачка питања, можемо донети одлуку о томе да ли ће дубински интервју служити да се дође до дефиниција ситуација самих учесника, да ли ће њихови искази служити као евиденција за откривање и описивање одређених неформланих структура друштвеног живота или ће дубински интервју служити да се провере хипотезе о узрочним везама или да се утврђене узрочне везе боље разумеју. Једноставније, тада ће бити јасније да ли ће интервју имати прелиминарне, дескриптивне, интерпретативне или узрочно-аналитичке задатке. Свакако, од теме и циљева истраживања ће зависити са ким ће се радити интервјуи и шта ће се од њих тражити. 
Када је реч о валдиности података добијених дубинским интервјуом, потребно је водити рачуна о многом аспектима. На првом месту јесте избор информаната са којима ће се водити разговори. У зависности од теме и циљева истраживања, потребно је одредити који чланови друштва поседују релевантна знања и искуства ${ }^{18}$. Затим, константно проверавање истинитости исказа током самог разговора, већ описаним техникама сучељавања са већ изнетим ставовима, запаженим контрадикцијама или захтевима за детаљним елаборацијама мишљења. На овом месту је неопходно да и сам истраживач касније преслушавајући разговоре или читајући транскрипте активно размишља о могућностима да су начин постављања питања или постављање у самом односу или чак статусне карактеристике учесника у разговору проузроковали одређене пристрасности у одговорима информаната, што значи да се ти делови евиденције морају изоставити из даље анализе. Другим речима, као и у свим другим квалитативним истраживањима, пожељна је секвенцијална анализа података која доприноси укупном квалитету прикупљење грађе и реализовању циљева студије. Свакако, у зависности од теме, информације се могу проверавати и упорећивањем са другим изворима, било да се консултује постојећа евиденција или да се организују нови интервјуи као вид додатне валидације добијених података.

На крају, дубински интервју није као такав етичан или неетичан, већ је у питању метода која пажљивом употребом даје могућност истраживачу да предупреди потенцијалне етичке проблеме. Критичким односом према целокупном процесу истраживања методом дубинског интервјуа, истраживач може да отклања или ублажава потенцијалне негативне ефекте дијалога на учеснике. Ту се на првом месту мисли на потребу да се непрестано има на уму неједнака дистрибуција моћи (Kvale, 2006), и да се из те перспективе рефлектује током дискусије, као и у фази анализе материјала и елаборације резултата. Слојевитост односа који се успоставља у интервјуу је довољно чврста основа да се процени поузданост исказа, али и да се донесе суд о томе шта је продукт специфичности релације (асиметрична дистрибуција моћи проузрокована родним, етничким, класним, језичким или другим праксама). Такође, такав однос отвара могућност да се потенцијално угрожавајући садржаји препознају и изоставе, било због тога што могу да компромитују испитаника, људе из његовог окружења или чак ширу групу којој припада. Дубински интервју пружа увид у све ове сегменте продукције и дистрибуције знања и стога можда у већој мери од других метода обавезује истраживача на контекстуализацију проблема и етички сензитивисан приступ.

\footnotetext{
${ }_{18}$ Овде је свакако важно питања броја информаната, тј. величине узорка, међутим, та тема захтева посебну обраду. Довољно је рећи да као и у случају других метода, у зависности од питања и циљева студије, величине и доступности популације из које се бира узорак, зависи и број информаната, а један од могућих принципа када треба престати са додавањем нових информаната је када истраживач процени да више не добија ново знање ни информације о предмету истраживања, тј. да је дошло до засићења.
} 


\section{Литература}

Almir B. Marvasti. 2004. Qualitative Research in Sociology. London/Thousand Oaks/ New Delhi: Sage Publications.

Archer, Dane, and Akert, M. Robin. 1980. The encoding of meaning: A test of three theories of social interaction. Sociological Inquiry 50(3-4): 393-419.

Berg, Bruce L. 2001. Qualitative Research Methods for the Social sciences - fourth edition. Boston: Allyn \& Bacon.

Briggs, Charles. 2007. Anthropology, interviewing and communicability in contemporary society. Current Anthropology, 48: 551-567.

Brinkmann, Svend and Steinar Kvale. 2005. Confronting the Ethics of Qualitative Research. Journal of Constructivist Psychology, 18:157-181.

Brinkmann, Svend. 2012. Qualitative Inquiry in Everyday Life: Working with Everyday Life Materials. London: Sage.

Brinkmann, Svend. 2013. Qualitative Interviewing. Oxford: Oxford Univerity Press

Denzin, Norman. 2001. Reflexive Interview and a Performative Social Science. Qualitative Research 1(1): 23-46.

Dilley, Patrick. 2004. Interviews and the Philosophy of Qualitative Research. The Journal of Higher Education, Vol. 75, No. 1: 127-132.

Duncombe, J., and Jessop, J. 2002. "Doing rapport" and the ethics of "faking friendship.", u: M. Mauthner, M. Birch, J. Jessop, \& T. Miller (ur.). Ethics in qualitative research. London: Sage.

Flick, Uwe. 2009. An Introduction to Qualitative Research - fourth edition. London: SAGE Publications.

Fontana, A. and J. Frey. 2000. The Interview: From Structured Questions to Negotiated Text, u: N. Denzin and Y. Lincoln (ur.). Handbook of Qualitative Research, 2nd ed., Thousand Oaks, CA: Sage.

Gubrium, J. and J. Holstein. 2002. From the Individual Interview to Interview Society, u: J. Gubrium and J. Holstein (ur.). Handbook of Interview Research: Context and Method. Thousand Oaks, CA: Sage.

Herod, Andrew. 1993. Gender Issues in the Use of Interviewing as a Research Method. The Professional Geographer 45(3): 305-317.

Holstein, J. and J. Gubrium. 1997. Active Interviewing, u: David Silverman (ur.). Qualitative Research: Theory, Method, and Practice. London: Sage.

Humphreys, Laud. 1970. Tearoom Trade: Impersonal Sex in Public Places. Chicago: Aldine.

Ian Borer, Michael and Andrea Fontana. 2012. Postmodern Trends: Expanding the Horizons of Interviewing Practices and Epistemologies, u: Gubrium, J. at al. (ur.). The SAGE Handbook of Interview Research - The Complexity of the Craft. Thousand Oaks, CA: Sage.

Johnson, J. M. 2002. In-depth Interviewing, u: J. Gubrium and J. Holstein (ur.), Handbook of Interview Research: Context and Method. Thousand Oaks, CA: Sage.

Johnson, John M. and Timothy Rowlands. 2012. The Interpersonal Dynamics of In-Depth Interviewing, u: Gubrium, J. at al. (ur.). The SAGE Handbook of Interview Research - The Complexity of the Craft. Thousand Oaks, CA: Sage. 
Kelman, C. Herbert. 1972. The rights of the subjects in social research: An analysis in terms of relative power and legitimacy. American Psychologist 27: 989-1015.

Kvale, Steinar. 1996. InterViews: An Introduction to Qualitative Research Interviewing. London and Thousand Oaks, CA: Sage.

Kvale, Steinar. 2006. Dominance Through Interviews and Dialogues. Qualitative Inquiry Vol. 13, No. 3: 480-500.

Latour, Bruno. 2000. When things strike back: a possible contribution of "science studies" to the social sciences. British Journal of Sociology, 50: 107-123.

Levine, Peter. 1998. Living without philosophy: On narrative, rhetoric, and morality. Albany, NY: State University of New York Press.

Maccoby, E.E. \& Maccoby, N. 1954. The interview: A tool of social science, u: G. Lindzey (ur.). Handbook of Social Psychology. Cambridge, MA: Addison-Wesley.

Mikecz, Robert. 2012. Interviewing Elites - Addressing Methodological Issues. Qualitative Inquiry 18 (6): 482-493.

Parker, Ian. 2005. Qualitative Psychology: Introducing Radical Research. Buckingham: Open University Press.

Patai, Daphne. 1987. Ethical problems of personal narratives, or, who should eat the last piece of cake?. International Journal of Oral History, 8(1): 5-27.

Polkinghorne, Donald. 2008. Qualitative Interviewing as a Moral Enterprise, u: Nielsen, Klaus et al. (ur.). A Qutalitaive Stance - Essays in honor of Steinar Kvale. Aarhus: Aarhus University Press.

Porter, Eileen J. 2000. Setting Aside the Identity-Furor: Staying her Story-Course of Same-ness. Qualitative Inquiry 6(2): 238-50.

Rubin, H.J. and Rubin, I.S. 2012. Qualitative Interviewing: The Art of Hearing Data third edition. Thousand Oaks, CA: Sage.

Schutz, Alfred. 1967. The phenomenology of the social world. Chicago: Northwestern University Press.

Seidman, Irving. 2006. Interviewing as Qualitative Research - A Guide for Researchers in Education and the Social Sciences - 3rd edition. London/New York: Teachers College Press.

Shuster, Evelyne. 1997. Fifty years later: The significance of the Nuremberg Code. The New England Journal of Medicine: 1436-1440.

Spradley, James P. 1979. The Ethnographic Interview. New York: Holt, Rinehart \& Winston.

Talmy, Steven. 2010. Qualitative interviews in applied linguistics: From research instrument to social practice. Annual Review of Applied Linguistics, 30: 128-148.

Warren, C.A.B. 2002. Qualitative interviewing, u: J.F. Gubrium \& J.A. Holstein (ur.), Handbook of Interview Research: Context \& Method. Thousand Oaks, CA: Sage.

Warren, Carol A. B. 2012. Interviewing as Social Interaction, u: Gubrium, J. at al. (ur.). The SAGE Handbook of Interview Research - The Complexity of the Craft. Thousand Oaks, CA: Sage.

Yin, K. Robert. 2011. Qualitative Research from Start to Finish. New York/London: The Gulford press. 


\section{Nemanja Krstić}

\section{ABOUT THE IN-DEPTH INTERVIEW METHOD}

Abstract: This paper represents an attempt to position the in-depth interview through the description of its main characteristics in relation to the existing classifications of the interview and the history of its use. Therefore, the argumentation begins with the description of the in-depth interview, and continues with systematic comparison in relation to the most widespread classification of interviews into structured, semistructured and unstructured. After relational determination, it goes deeper into the analysis of the specificity of the in-depth interview method, through its analytical advantages, theoretical grounding and general connection with the ethical dilemmas which researchers must be aware of.

Key words: in-depth interview, social context, personal interpretations and knowledge, phenomenology, constructionism, ethical issues 